\title{
Henryk Majkrzak SCJ, Watykan. Papieskie formacje zbrojne, Wydawnictwo Marek Derewiecki, Kęty 2013, ss. 170 + 64 plansze ilustrowane.
}

Tematyka papieskich formacji zbrojnych zasadniczo nie budziła zainteresowania polskich naukowców ${ }^{1}$, w przeciwieństwie do ich kolegów z innych krajów, a zwłaszcza z Włoch, Niemiec, Szwajcarii i Francji². Mogłoby się to wydawać o tyle zaskakujące, że szczególnie ze względu na pontyfikat papieża rodaka - św. Jana Pawła II (1978-2005), kwestie dotyczące Watykanu stały się nam bliskie, a polscy badacze mieli relatywnie łatwy dostęp przynajmniej do zbiorów Biblioteki Watykańskiej. Tendencja niedostrzegania współczesnych jednostek papieskich zmieniła się dopiero w ostatnich kilku latach. Prawdopodobnie miały na to wpływ (szkoda tylko, że tak późno): zakończony pontyfikat Karola Wojtyły, jego beatyfikacja (1 maja 2011 r.) i kanonizacja (27 kwietnia 2014 r.) oraz uroczystość 500-lecia Papieskiej Gwardii Szwajcarskiej (PGS - 22 stycznia 2006 r.).

Jako pierwszy w Polsce książkę poświęconą całkowicie tematowi Gwardii Szwajcarskiej - głównej formacji papieskiej - napisał Zbigniew Witkowski,

1 Jedynym wyjątkiem, była praca Zdzisława Morawskiego, Sacco di Roma, Kraków 1923. Dotyczyła ona jednak tylko wybranego zagadnienia z historii Papieskiej Gwardii Szwajcarskiej, jakim było złupienie Rzymu w dniach 6-14 maja 1527 r. przez wojska króla Francji Karola V.

2 Tylko w XXI wieku, głównie ze względu na uroczystość 500-lecia istnienia Papieskiej Gwardii Szwajcarskiej, wydano następujące pozycje: G. Cantelli, Die Päpstliche Schweizergarde: zeitgenössische Stiche und Aquarelle vom 16. bis zum 20. Jahrhundert aus der Privatsammlung des Hauptmanns Roman Fringeli, Regensburg 2006; D. Delcuratolo, Storia Della Guardia Svizzera Pontificia e Dei Corpi Militari Pontifici Disciolti nel 1970, Varese 2006; P. M. Krieg, Die Schweizergarde in Rom 1506-2006, Zürich 2006 (wznowienie wydania sprzed kilkudziesięciu lat); Les Suisses du Pape. 500 ans au Vatican. Ouvrage commémoratif de l'exposition du Musée des Suisses dans le Monde pour le Jubilé 1506-2006, édité par N. Chavannes, A. Zurfluh, Geneve 2006; S. Meier, K. Kiermeier, Treu, redlich und ehrenhaft. Die Schweizergarde in Bildern früher und heute, Dachau 2007; G. Morello, V. Pranzini, Gli Angeli Custodi del Papa. 500 anni della Guardia Svizzera Pontificia, Lugo 2006; U. Nersinger, G. P. Weishaupt, Pontificia Cohors Helvetica (1506-2006), Bonn 2005; C. R. M. Richard, La guardia svizzera pontificia nel corso dei secoli, Milano 2005; R. Royal, The Pope's Army. 500 Years of the Papal Swiss Guard, New York 2006; S. Sapin, Garde Suisse au Vatican: Ombre et lumière, Yens sur Morges 2004; C. Schweizer, H. De Weck, Hirtenstab Und Hellebarde: Die Papstliche Schweizergarde in Rom 1506-2006, Zürich 2006; A. Serrano, Die Schweizergarde der Päpste, wyd. 3, Dachau 2005; R. Stampfli, Die Päpstliche Schweizergarde 1870-1970, Solothurn 2004; R. Walpen, Päpstliche Schweizergarde: acriter et fideliter - tapfer und treu, Paderborn-München-Wien-Zürich 2005; The Swiss Guard. Celebrating 500 Years of Papal Service, ed. by M. Cupellaro, P. Fiorletta, New Haven, CT 2006; D. Alvarez, The Pope's Soldiers. A Military History of the Modern Vatican, Lawrence, KS 2011; R. Affinatti, Soldati del Papa, Dall'antichità ai giorni nostri, Edizioni Chillemi - nr 13, Roma 2014; D. Geisser, E. Niederberger, Päpstliche Schweizergarde - Buon Appetito: Rezepte, Geschichten und prominenten Porträts, Thun 2014. 
profesor prawa na Uniwersytecie Mikołaja Kopernika w Toruniu3. Jak sam przyznawał we wstępie do swojej monografii, napisał ją hobbistycznie, a znaczną rolę odegrała $\mathrm{w}$ tym pewna pocztówka $\mathrm{z}$ gwardzistami wysłana przez profesor Karolinę Lanckorońską do córki Autora w latach 80. XX wieku4.

Kolejnym Autorem monografii dotyczących papieskich sił zbrojnych jest ks. dr hab. Henryk Majkrzak55. W 2011 r. wydał on książkę dotyczącą Watykanu', której część (s. 171-208) poświęcił oddziałom utrzymującym bezpieczeństwo i porządek w tym państwie. Z kolei w 2013 r. opublikował monografię w całości poświęconą żołnierzom i policjantom, służącym następcom św. Piotra ${ }^{7}$, która stanowi przedmiot niniejszej recenzji.

$\mathrm{Na}$ wstępie należy nadmienić, że aktualnie tendencja wydawania w Polsce książek poświęconych Gwardii Szwajcarskiej została podtrzymana. Ze względu na wspomnianą wcześniej kanonizację Jana Pawła II opublikowano w naszym kraju w 2014 r. dwa interesujące świadectwa o papieżu opowiedziane przez gwardzistów szwajcarskich - byłego komendanta Piusa Segmüllera i halabardzisty Andreasa Widmera ${ }^{8}$.

$\mathrm{Na}$ papieskie formacje zbrojne składały się od 1870 r., czyli od czasu, kiedy papieże stali się więźniami Watykanu, zasadniczo cztery jednostki: Papieska Gwardia Szwajcarska ${ }^{9}$, Gwardia Szlachecka ${ }^{10}$, Gwardia Palatyńska (Pała-

\footnotetext{
3 Z. Witkowski, „Mężnie i wiernie”. Papieska Gwardia Szwajcarska. Historia chwaty, Toruń 2010.

4 Zainteresowanych odsyłam do wymienionej wcześniej monografii na strony $11-15$ i do stosownych fotografii.

5 Autor, oprócz pracy naukowej na UKSW w Warszawie i pełnienia posługi kapłańskiej, należy do Zgromadzenia Księży Najświętszego Serca Jezusowego (Sercan - stąd skrót SCJ).

6 H. Majkrzak, Watykan. Wszytko to, co chcielibyście wiedzieć, Kraków 2011.

7 Idem, Watykan. Papieskie formacje zbrojne, Kęty 2013.

8 Mój święty szef. Komendant Pius Segmüller w rozmowie z ks. Robertem Bielem, red. R. Biel, Kraków 2014; A. Widmer, Strażnik świętego Papieża. Świadectwo o Janie Pawle II, wstęp G. Wiegel, Kraków 2014.

9 Papieska Gwardia Szwajcarska (PGS) od 22 stycznia 1506 r. stanowi osobistą straż papieską. Jest to jedna z najstarszych formacji zbrojnych na świecie. Aktualnie PGS liczy 110 ludzi, co stanowi około $15 \%$ mieszkańców Watykanu. Służą w niej katolicy pochodzący z odmiennych, pod względem językowym, kantonów Szwajcarii. Językiem dominującym w Gwardii jest język niemiecki (niem. Päpstliche Schweizergarde), występuje też język francuski (fr. Garde Suisse Pontificale) oraz włoski (wł. Guardia Svizzera Pontificia). Od tych dwóch ostatnich nazw przyjął się oficjalny skrót Gwardii - GSP - występujący m.in. na klamrach pasów używanych przez gwardzistów.

10 Gwardia Szlachecka (wł. Guardia Nobile) ochotnicza formacja eskortująca papieży, powstała 11 maja 1801 r. jako oddział kawalerii, w 1870 r. przemianowana na jednostkę piechoty. Wstęp do niej mieli jedynie szlachetnie urodzeni Włosi, którzy odbyli zasadniczą służbę wojskową. Odział występował tylko w czasie publicznych wystąpień papieży lub jako eskorta w podróżach do rezydencji papieskich. Jednostka została zlikwidowana 14 września 1970 r. przez papieża Pawła VI.
} 
cowa) ${ }^{11}$, Żandarmeria Papieska' ${ }^{12}$. Na mocy decyzji papieża Pawła VI z 14 września 1970 r. Gwardia Szlachecka i Gwardia Palatyńska uległy rozwiązaniu. Obecnie funkcje ochrony papieskiej i służbę wartowniczą sprawują, głównie przy wejściach do Watykanu, gwardziści szwajcarscy ${ }^{13}$. Z kolei żandarmi, jak sama nazwa wskazuje, pełnią funkcje policyjne oraz straż w wybranych miejscach Watykanu ${ }^{14}$.

W swojej książce H. Majkrzak przedstawia najważniejsze informacje dotyczące papieskich formacji zbrojnych. We wstępie (s. 8-16) Autor - według mnie słusznie - odnosi się do zagadnień wprowadzających do tematu czyli związanych z instytucją papiestwa i organizacją Państwa Watykańskiego. Zasadniczą część monografii stanowi opis działalności Papieskiej Gwardii Szwajcarskiej (rozdział 1, s. 19-89) i Żandarmerii Watykańskiej (rozdział 2, s. 90-123) - czyli aktualnych formacji zbrojnych i policyjnych Watykanu. Poświęcenie większej części pracy dwóm wymienionym jednostkom nie budzi wątpliwości. W tym miejscu zauważyć należy jedynie, że Autor Gwardii poświęcił 70 stron, a Żandarmerii tylko 33.

W rozdziale 1 złożonym aż z 31 krótkich podrozdziałów H. Majkrzak koncentruje się na takich zagadnieniach, jak: historia GSP (s. 20-36) ze szczególnym uwzględnieniem lat 1506-1527 (s. 20-29), warunki przyjęcia i rekrutacja do służby, życie codzienne i przebieg służby. Szczególnie warty podkreślenia jest dokładny opis święta Gwardii - dnia przysięgi rekrutów (6 maja). Ponadto Autor szczególowo omawia kwestie związane z umundurowaniem i uzbrojeniem jednostki. O tych ostatnich zagadnieniach $\mathrm{H}$. Majkrzak pisze $\mathrm{z}$ dużą swobodą i wiedzą. Nie pomija także jednego z najtragiczniejszych wydarzeń w historii Gwardii (4 maja 1998 r.), czyli do dzisiaj niewyjaśnionego morderstwa jej komendanta Aloisa Estermanna i jego żony Gladys Meza Romero dokonanego przez kaprala Cédrica Tornaya, który z kolei popełnił samobójstwo. H. Majkrzak przedstawia też ówczesne dowództwo Gwardii. Większość wyższych oficerów

11 Gwardia Palatyńska (Honorowa) zwana też Strażą Pałacową (wł. Guardia Palatina d'Onore) powstała 14 grudnia 1850 r. jednostka piechoty, której głównym zadaniem była służba papieżom. Głównie chodziło tu o służbę honorową i porządkową podczas uroczystości z udziałem papieża; por. przypis 10 .

12 Żandarmeria Watykańska (wł. Gendarmeria Vaticana) jednostka policji powstała 14 lipca $1816 \mathrm{r}$.

13 Gwardziści pełnią straż przy następujących wejściach do Watykanu: Bramie Spiżowej, Bramie Dzwonów, Bramie św. Anny, wejściach Petriano i Perugino oraz wejściach do Bazyliki św. Piotra i Muzeów Watykańskich. Ponadto posterunki Gwardii znajdują się m.in. w Pałacu Watykańskim (np. przed apartamentami papieskimi) a patrole PGS można napotkać w Muzeach i Ogrodach Watykańskich, na Placu i w Bazylice św. Piotra.

14 Np. żandarmi mają swoje posterunki m.in. za Bramą św. Anny i przed Dziedzińcem Belwederskim. 
tej formacji pochodzi z nominacji papieskich, a ich służba trwa zazwyczaj kilka lat. Zdarzają się jednak oficerowie, których kariera rozpoczęła się od stopnia zwykłego halabardzisty. Jako przykład można tu podać Christopha Grafa, który wstąpił w szeregi Gwardii w 1987 r. i w ciągu 27 lat służby osiągnął stopień podpułkownika i zastępcy komendanta.

Autor z jednej strony ze znawstwem porusza się między poszczególnymi zagadnieniami dotyczącymi GSP, z drugiej jednak - tok narracji zaburzają liczne powtórzenia, odesłania i niedopowiedzenia ${ }^{15}$, które nawet dla czytelnika orientującego się w opisywanej tematyce, mogą utrudniać przyswojenie tekstu. H. Majkrzak dość swobodnie posługuje się chronologią, co również nie ułatwia życia czytelnikowi.

Autor wspomina (s. 20) o regulaminie PGS z 1976 r. ${ }^{16} \mathrm{~W}$ innym miejscu (s. 74) nadmienia, że otrzymał fragment „Regulaminu” z określeniem ubioru i uzbrojenia formacji. Niestety Autor nie podał, z którego roku pochodził ów regulamin. Z kolei kilka stron dalej zauważa (s. 80), że na podstawie art. 37 regulaminu (brak daty - dop. Ł.N) gwardzista, który odsłużył pięć lat, może otrzymać pozwolenie na zachowanie munduru i beretu.

Szkoda, że H. Majkrzak wyraźnie nie stwierdził, a przynajmniej nie uczynił tego na stronach 74 i 80, że posługiwał się regulaminem z 1976 r. Warto zatem zaznaczyć, że po tym regulaminie wydano kolejną jego wersję z 1997 r., a aktualnie już od kilku lat obowiązuje nowy regulamin zaaprobowany 16 stycznia $2006 \mathrm{r}$. przez papieża Benedykta XVI, a podpisany przez ówczesnego watykańskiego sekretarza stanu, kardynała Angelo Sodano. Wszedł on w życie 22 stycznia 2006 r. z okazji 500-lecia Papieskiej Gwardii Szwajcarskiej i obowiązuje do tej pory. Regulamin ten powinien być znany Autorowi w momencie przygotowywania omawianej monografii. Wskazane przez H. Majkrzaka pozwolenie na zachowanie munduru po pięciu latach służby jest aktualnie uregulowane $w$ art. 39., a nie w 37, jak uważa Autor. Z drobniejszych uwag wypada wspomnieć, że nie do końca można zgodzić się z twierdzeniem Autora: „Często [czarne] moriony mają gwardziści pełniący wartę w Bramie Spiżowej” (s. 78). Liczne źródła ikonograficzne (zdjęcia, pocztówki) wyraźnie pokazują, że gwardziści pełniący służbę w tym miejscu, przynajmniej do lat 90 . XX wieku, nosili berety, a nie hełmy. Wśród setek fotografii i pocztówek znanych piszącemu niniejszy tekst, a doty-

15 Przykładowo Autor wymienia świętych patronów PGS (Marcina z Tours, Sebastiana, Mikołaja z Flüe) na stronie 43 i powtarza na stronie 53. Z kolei na tej ostatniej stronie czytelnik dowiaduje się, że „Ciało kaprala Cédrica Tornay matka pogrzebała w Szwajcarii”, a wyjaśnienie, kim był ów kapral i jaką rolę odegrał, można odnaleźć dopiero na stronie 70. Podobnie nieskładne i powtarzane są informacje o sierżancie Marcelu Riedi (s. 65 i 87), itp.

16 Chodzi tu o Regulamin Organizacyjny, Dyscyplinujący i Administracyjny Papieskiej Gwardii Szwajcarskiej zaaprobowany 28 czerwca 1976 r. przez papieża Pawła VI. 
czących Bramy Spiżowej, na żadnej nie przedstawiono gwardzistów w hełmach. Aktualnie to ostatnie nakrycie głowy jest używane przez gwardzistów na tym posterunku, ale głównie w niedziele i święta.

Rozdział 2 złożony z 22 podrozdziałów Autor poświęca Żandarmerii Watykańskiej. Opisuje w nim dwóch ostatnich szefów służb policyjnych Watykanu Camillo Cibina i Domenico Gianiego. Ponadto przedstawia krótką historię jednostki oraz przybliża m.in. wymogi stawiane kandydatom na żandarmów. Dodatkowo opisuje takie kwestie dotyczące służby policyjnej, jak: sztandar, przysięga, święto, orkiestra. Autor omawia także umundurowanie jednostki, jej uzbrojenie i wyposażenie. Należy docenić, że H. Majkrzak jako pierwszy w Polsce podjął się omówienia tematyki Żandarmerii Watykańskiej.

W kolejnych rozdziałach (3-6) H. Majkrzak opisuje zarówno historyczne papieskie formacje zbrojne, takie jak: Gwardia Palatyńska, czy Gwardia Szlachecka (s. 128-133); jak i aktualne służby, typu: straż pożarna, służba medyczna, czy cywilna służba porządkowa. W rozdziałach tych Autor jeszcze bardziej zaburzył dysproporcje między ich pojemnością. I tak rozdział 3. (Watykańska straż pożarna) liczy 3 strony [sic!], a rozdział 4. (Sanpietrini) aż 1 [sic!] stronę. Trochę lepiej przedstawia się sytuacja $z$ rozdziałem 5. (Historyczne formacje zbrojne papieża) złożonym z 23 stron, ale już nie z 6. (Ochrona Watykanu ze strony państwa włoskiego), liczącym 10 stron.

Bibliografia przedstawiona przez H. Majkrzaka nie do końca przekonuje. Autor nie sięgnął do licznych książek wymienionych chociażby w przypisie 2 . do niniejszej recenzji, nie mówiąc już o aktualnych regulaminach poszczególnych formacji dostępnych w Bibliotece Watykańskiej.

$\mathrm{Na}$ uwagę zasługuje część ilustracyjna książki. Autor sporym nakładem pracy i przy „lekkim wsparciu” regulaminu PGS z 1976 r. przedstawia papieskie formacje zbrojne: historyczne i obecne. Na 64 stronach Autor zamieszcza 77 własnoręcznie wykonanych plansz, na których ukazuje prawie wszystkie możliwe aspekty umundurowania (pomija tylko kwestie opisu odznaczeń), w tym szczególnie nakryć głowy, uzbrojenia, stopni, a nawet środków transportu Papieskiej Gwardii Szwajcarskiej (plansze II-XXXIV) oraz Żandarmerii Watykańskiej (pl. XXXV-LII). Warto nadmienić, że oprócz aktualnych elementów wyposażenia, H. Majkrzak przedstawia na 10 planszach (pl. XXV-XXXIV) gwardzistów w mundurach historycznych. Posiłkuje się przy tym rycinami z XIX wieku oraz pocztówkami z początku XX wieku (przykładowo pl. XXVI). Podobny zabieg stosuje względem żandarmów, gdzie na 7 planszach przedstawia ich ubiór z przeszłości (pl. XLVI-LII). Dodatkową zaletę stanowi umieszczenie przez Autora plansz dotyczących nieistniejących już papieskich formacji zbrojnych: Gwardii Szlacheckiej (pl. LIII-LVIII), Gwardii Palatyńskiej (pl. LX-LXVI), czy innych jednostek historycznych (pl. LXVII-LXXIV). Listę uzupełniają trzy plansze dotyczące straży pożarnej i włoskich formacji policyjnych wspomagających ochronę Watykanu (pl. LXXV-LXXVII). Wszystkie plansze wykonane są niezwykle sta- 
rannie i z wielką dbałością o szczegóły. Część ilustracyjna książki zasługuje zatem, według mojej oceny, na wyrazy uznania.

Reasumując: moim zdaniem należałoby monografię podzielić na cztery rozdziały, w tym dwa poświęcone w całości Gwardii Szwajcarskiej, jeden Żandarmerii Papieskiej, a ostatni - innym, aktualnym służbom watykańskim. Kładę nacisk na słowo ,aktualnym”, gdyż jedynie około $15 \%$ treści książki zajmuje omówienie historycznych formacji zbrojnych. Pozostałe 85\% dotyczy obecnych jednostek watykańskich: PGS, ŻW i wszelkich służb pomocniczych. Według mnie, opis dotyczący historycznych oddziałów papieskich, należałoby umieścić w skróconej wersji we wstępie. Po dokonaniu tych „zabiegów” metodologicznych i usunięciu powtórzeń oraz uzupełnieniu bibliografii recenzowana pozycja zyskałaby na wartości.

Nie można zaprzeczyć, że Autor posiada dużą wiedzę na temat papieskich formacji zbrojnych, a w szczególności Papieskiej Gwardii Szwajcarskiej. Nie zawsze jednak stan wiedzy przekłada się na tok narracji, który jest dość chaotyczny, niespójny i pełen powtórzeń. Autor nie odnosi się także do aktualnego regulaminu PGS. Nie przekonuje również zastosowany przez H. Majkrzaka podział na poszczególne rozdziały i ich niekiedy rażąca dysproporcja. Z kolei wśród zalet monografii można umieścić 77 ilustrowanych plansz skrupulatnie odtworzonych przez Autora, które zdecydowanie wzbogacają treść książki oraz przedstawienie życia gwardzistów na co dzień i od święta. Na plus Autorowi można zaliczyć także to, że z dbałością o szczegóły ukazuje system ochrony Państwa Watykańskiego - system - który zasadniczo (za wyjątkiem zamachu na papieża Jana Pawła II i wewnętrznej sprawy zabójstwa jednego z komendantów Gwardii Szwajcarskiej) do tej pory się sprawdza. Pracę H. Majkrzaka można zatem polecić przede wszystkim entuzjastom uzbrojenia i umundurowania Papieskiej Gwardii Szwajcarskiej czy Żandarmerii Watykańskiej.

Łukasz Niewiński

Wydział Historyczno-Socjologiczny

Uniwersytet w Białymstoku 